\title{
DEFINISI DAN FALSAFAH TQM
}

Oleh:

\section{Mardiyono}

\author{
Fakultas Agama Islam, Jurusan Manajemen Pendidikan Islam \\ Universitas Nurul Jadid \\ Email: diyonzdiyon2@@mail.com
}

\begin{abstract}
ABSTRAK
Sering kita lihat di era global sekarang ini banyak problem mutu yang dihadapi dalam dunia pendidikan, contoh mutu lulusan, mutu pengajaran, bimbingan dan latihan dari para guru, serta mutu profesionalisme dan kinerja guru. Mutu-mutu tersebut terkait dengan mutu manajerial para pimpinan pendidikan, keterbatasan dana dan kurangnya dana yang masuk, sarana, dan prasarana, fasilitas pendidikan, media, sumber belajar, alat dan bahan untuk latihan, situasi di lingkungan sekolah, keadaan pendidikan, dan kurang di dukungnya dari pihak yang bertanggung jawab dengan pendidikan tersebut dan juga tingkat rendahnya mutu kelulusan.
\end{abstract}

\section{PENDAHULUAN}

Sering terjadinya masalah yang di buat para lulusan pendidikan yang tidak bermutu, upaya-upaya atau program untuk meningkatkan mutu pendidikan merupakan hal yang amat penting. Seiring dengan kejadian tersebut,sehingga pemerintah mengeluarkan peraturan undang-undang untuk mendorong peningkatan kualitas pendidikan yang ada di Indonesia. Undang - undang Sisdiknas nomor 20 Tahun 2003 menegaskan bahwa evaluasi mutu pendidikan 
harus di tekankan, baik di pernyataan yang telah di susun dan di rangkai menjadi satu kesatuan agar di terapkan. Dan ada juga sekarang peraturan dari pemerintah Nomor 19 Tahun 2005 tertulis bahwa ketetapan Standar Nasional Pendidikan itu memiliki tujuan untuk menciptakan pendidikan yang ada di indonesia ini menjadi pendidikan yang sangat bermutu.

\section{A. Defenisi Quality (Mutu)}

Membahas tentang kualitas atau mutu, sumber daya manusia pendidikan ikut berperan sangat penting dalam meningkatkan tingkat baik buruknya di sumber daya manusia tersebut. Peningkatan kualitas atau mutu pendidikan merupakan suatu proses yang mengalami pembaruan hingga menjadi suatu kesatuan yang utuh dengan proses yang telah ditingkatkan oleh sumber daya manusia itu sendiri. Sadar akan pentingnya suatu proses dalam meningkatkan kualitas yag ada pada sumber daya manusia tersebut, maka dari itu pemerintah ingin memperbaiki dan terus berupaya mewujudkan amanat tersebut dengan usaha membangunan pendidikan tersebut agar menjadi lebih bermutu dan berkualitas tinggi. ${ }^{1}$

Di dalam kamus ilmiah populer mutu secara etimologi itu di maknai sebagai kualitas; derajat; tingkat. Dan di dalam buku bahasa Inggris Quality itu bermakna kualits. Dan secara bahasa latin mutu di artikan sebagai berikut. $^{2}$

Umumnya, mutu tersebut mempunyai arti sendiri yaitu derajat (tingkat) dimana unggulnya suatu barang (hasil upaya/kerja) baik berupa barang maupun jasa. ${ }^{3}$ Quality (Mutu) merupakan seseorang yang percaya diri dan mandiri, sedangkan aktivitas yang kaku tidak sama sekali

\footnotetext{
${ }^{1}$ Umaedi, Manajemen Peningkatan Mutu (April, 1999).

${ }^{2}$ Pius A. Partanto, Kamus Ilmiah Populer (Surabaya: Arkola, 1994), h. 505

${ }^{3}$ Umaedi, Manajemen Peningkatan Mutu ( April, 1999).
} 
membantu. Makna mutu dari saking banyaknya di dunia ini membuat kita kebingungan untuk memahaminya. Ada beberapa dampak praktis yang penting akan munculnya dari perbedaan makna tersebut. ${ }^{4}$

Menurut Crosby mutu adalah sesuai tingktanya (Conformance to requirement),seperti memiliki standar mutu yang telah ada atau telah ditentukan, baik inputnya, prosesnya maupun outputnya. Dari semua itu, mutu pendidikan yang diadakan di sekolah diharuskan untuk memiliki baku standar mutu pendidikan. Mutu dalam konsep Deming adalah yang berkaitan dengan fasilitas pasar. Dalam konsep Deming, pendidikan yang bermutu ialah pendidikan yang bisa menghasilkan keluaran, baik dari pelayanan dan maupun lulusan yang cocok dibutuhan atau yang diharapan pelanggannya. Sedangkan Fiegenbaum mengartikan mutu adalah memberi kepuasan dan layanan kepada pelanggan dengan sepenuhnya (fullcustomer satisfaction). Dalam artian,yang disebut sekolah yang bermutu adalah sekolah memberikan layanan yang baik dan membuat pelanggan puas akan layanannya, baik dari pelanggan internal maupun eksternal. ${ }^{5}$

Mutu menurut Carvin itu sebagaimana yang dikutip oleh Nasution, ialah suatu keadaan yang mengejar tujuan-tujuan meraka dengan aktif dan penuh semangat yang berkaitan dengan produknya tersebut, manusia/tenaga kerja, proses dan tugas, dan lingkungan yang melebihi harapan terhdap pelanggan atau konsumen. Selera pelanggan selalau berubah pada produk tersebut, sehingga kualitas produk juga harus berubah atau disesuaikan di setiap waktunya. Dengan perubahan mutu produk tersebut, sangat diperlukan perubahan dari tenaga kerja, perubahan proses dan tugasannya, serta perubahan lingkungan organisasi agar produk

\footnotetext{
${ }^{4}$ Ahmad Ali Riyadi, Manajemen Mutu Pendidikn (Jogjakarta: IRCiSoD, 2007), h.51

${ }^{5}$ Crosby, Philip B., Quality is Free (New York : New American Library, 1979), h.58.
} 
dapat memenuhi atau melebihikan apa yang diharapan pelanggan. ${ }^{6}$

Menurut Edward Sallis ada beberapa konsep tentang mutu. Pertama mutu sebagai konsep mutlak. Konsep tersebut kualitas atau mutu adalah dicapainya standar yang tertinggi di dalam pekerjaan, produk, dan layanan yang tidak bisa di capai. ${ }^{7}$ Kedua mutu tersebut sebagai konsep hubungan. Dalam konsep ini kualitas atau mutu masih ada kesempatan untuk meningkatkan kualitasnya. Kualitas atau mutu adalah sesuatu yang masih bisa ditambah tingkatannya. Akan tetapi dalam tingktannya tersebut harus berkualitas baru tingkatannya tersebut di bilang berkualitas. ${ }^{8}$ Ketiga adalah kualitas menurut pelanggan. Dalam definisi ini mutu sebagai kepuasan pelanggan dan keinginan dan kebutuhan pelanggan.Definisi yang dikemukakan oleh pelanggan sangat berperan penting, karena itu dari beberapa pelanggan pasti akan memberi upah yang lebih karna mutu yang di berikan sangat baik, tanpa melihat tipe produk yang diberikan. ${ }^{9}$

Dari pengertian diatas, dapat disimpulkan bahwa Quality (Mutu) merupakan unggulnya suatu produk,barang atau jasa yang proses kerjanya lebih baik dari rencana yang telah di buat dengan sebaik baiknya. Mutu atau kualitas merupakan suatu tujuan akhir dari sebuah proses panjang yang dilaksanakan oleh organisasi. Mutu termasuk sebuah jaminan dari lembaga yang sudah ada kepada pelanggannya. Pelangganlah yang akan menentukan apakah lembaga tersebut mempunyai mutu produknya (barang atau jasa) baik atau buruknya. Karena merekalah orang yang di layani, Dan merekalah hanya yang dapat memilih dan menentukan barang

${ }^{6}$ Nasution, Manajemen Mutu Terpadu (Total Quality Management) (Jakarta : Ghalia Indonesia, 2001), h.16

${ }^{7}$ Dede Rosyada, Paradigma Pendidikan Demokratis; Sebuah Model Perlibatan Masyaraka dalam Penyelenggaraan pendidikan (Jakarta: Kencana, 2004), h. 285

${ }^{8}$ Ibid, h.286

${ }^{9}$ Ahmad Ali Riyadi, Manajemen Mutu Pendidikan (Jogjakarta: Irchisod, 2007), h.56-57 
mana yang layak untuk di pakek. Dan untuk itu lembaga harus menjaga kualitasnya atau meningkatkan kualitasnya agar lebih terjaga dan tidak ditilnggakan oleh pelanggan.

Dari beberapa penjelasan diatas barusan yang berkaitan dengan mutu atau kualitas dan dibawah ini ada beberapa penjelasan mutu yang dikatakatan bermutu, yakni:

1. Kualitas yang harus berusaha untuk memenuhi apa yang ingin pelanggan inginkan.

2. Kualitas yang terdiri dari produk, jasa, manusia, proses, dan lingkungan.

3. Kualitas merupakan kondisi yang berubah rubah (apa yang sudah berkualitas di saat ini pasti di suatu saat nanti akan berubah) karna itu karyawan harus bersiap siap untuk mencegah perubahan tersebut (kondisi) karna di dunia ini pasti ada yang namanya perubahan.

Kita dapat melihat pendidikan yang ada kualitasnya dilingkungan organisai tersebut melalui dimensi - dimensi kualitas yang harus nyata oleh pucuk pimpinan bekerja sama dengan warga sekolah yang ada dalam lingkungan tersebut. Menurut Hadari Nawawi, ada beberapa dimensi di bawah ini: ${ }^{10}$

1. Dimensi Kerja Organisasi

Yang dimaksud kinerja dalam arti unjuk perilaku dalam bekerja itu yang mengerjakan pekerjaan dengan positif, merupakan gambaran konkrit dari kemampuan mendayagunakan sumber-sumber kualitas, yang bisa menghasilkan keberhasilan, mempertahankan dan mengembangkan eksistensi organisasi (sekolah).

2. Iklim Kerja

\footnotetext{
${ }^{10}$ Hadari Nawawi; Manajemen Strategik, Gadjah Mada Pers : Yogyakarta, 2005, h.141
} 
Penggunaan sumber-sumber kualitas secara intensif akan membuat baik di lingkungan organisasi. Di dalam kombinasi pekerja yang dilakukan dengan kebersamaan akan menimbulkan kerjasama yang tepat dan benar dalam tim kerja tersebut, yang saling menghargai dan menghormati pendapat, kreativitas, inisiatif dan inovasi agar bisa meningkatkan kualitas.

3. Nilai Tambah

Penggunaaumber-sumber kualitas secara tepat dan benar akan membuat nilai bertambah atau keistimewaan tambahan sebagai pelengkap dalam melaksanakan tugas pokok dan hasil yang dicapai oleh suatu organisasi. Nilai tambah yang jeals terlihatnya rasa puas dan berkurangnya keluhan dari yang dilayani (siswa).

4. Kesesuaian dengan Spesifikasi

Pendayagunaan sumber-sumber kualitas secara tepat dan efisien bermanifestasi pada kemampuan personil untuk menyesuaikan proses pelaksanaan pekerjaan dan hasilnya dengan karakteristik operasional dan standar hasilnya berdasarkan ukuran kualitas yang disepakati.

\section{B. Definisi Total Quality Management.}

Menurut Gaspersz ${ }^{11}$ Total Quality Manajemen didefinisikan sebagai suatu cara meningkatkan kesetabilan secara berkelanjutan (continuous performance improvement) di setiap tingkatan operasi atau proses, dalam setiap tempat fungsinya dari suatu organisasi, dengan menggunakan semua sumber daya manusia dan modal yang tersedia.

Menurut Purnama ${ }^{12}$ TQM. adalah suatu rangkaian dengan semacam

\footnotetext{
${ }^{11}$ Vincent Gaspersz; Total Quality Manajemen. PT Gramedia Pustaka Utama: Jakarta, 2001, h 04 .

12 Nursya'bani Purnama. Manajemen Kualitas Perspektif Global. Ekonisia, Yogyakarta, 2006. h 51.
} 
alat, teknik, dan kebijakan yang disenikan untuk menciptakan budaya perusahaan yang lebih fokus kepada konsumen, dan di ikuti oleh pekerja yang aktif, dan perbaikan kualitas terus-menerus dengan tujuan agar sesuai dengan harapan konsumen." Hitt, Ireland dan Hoskisson ${ }^{13}$ mengatakan "TQM adalah hasil pengembangan pemimpin yang menekankan komitmennya yang ada di sebuah organisasi kepada pelanggan agar bisa terus memperbaiki proses pendekatan dan permasalahan,yang dibantu oleh data, didasarkan untuk kelompok-kelompok dan tim karyawan."

\section{Prinsip Total Quality Management}

TQM merupakan suatu satu tugasan yang berupaya melaksanakan sistem manajemen kelas dunia. Seperti kita mempunyai suatu sistem itu semua hanya dibuat untuk tujuan yang kita gapai

Tujuan TQM ialah memberikan kepuasan untuk memberikan suatu produk atau jasa berkualitas agar bisa memenuhi kebutuhan dan kepuasan pasar konsumen (sustainable satisfaction) yang pada gilirannya akan menimbulkan pembelian berkesinambungan sehingga dapat meningkatkan produktivitas produsen mencapai skala ekonomis dengan akibat penurunan biaya produksi.

Untuk itu,dibutuhkan suatu perubahan besar dalam budaya dan sistem nilai pada organisasi. Dalam bukunya Nasution, ${ }^{14}$ menurut Hensler dan Brunell (dalam Scheuing dan Christopher, 1993 : 165-166), ada empat prisip utama dalam TQM tersebu;

1. Kepuasan Pelanggan

Di dalam TQM, Tentang mengenai kualitas dan pelanggan

${ }^{13}$ Hitt,Michael A, R.Duane Ireland dan Robert E. Hoskisson. Manajemen Strategis : Daya Saing dan Globalisasi. Salemba Empat, Jakarta, 2001.h 223.

${ }^{14}$ Nasution Manajemen Mutu Terpadu ( Total Quality Management). Ghalia Indonesia: Jakarta, 2004. h. 30. 
diperluas. Kualitas tidak hanya bermakna kecocokan dengan tertentu, akan tetapi bagus tidaknya kualitas tersebut ditentukan oleh pelanggan. Srimindarti mengemukakan dalam tulisannya bahwa, Kunci persaingan dalam pasar global adalah kualitas total yang mancakup penekanan-penekanan pada kualitas produk, kualitas biaya atau harga, kualitas pelayanan, kualitas penyerahan tepat waktu, kualitas estetika dan bentuk-bentuk kualitas lain yang terus berkembang guna memberikan kepuasan terus menerus kepada pelanggan agar tercipta pelanggan yang loyal (Hansen dan Mowen, 1999). Kebutuhan pelanggan harus dipenuhi dengan bagus/baik dalam segala aspek, termasuk harga barang, keamanan dan ketepatan waktu. Oleh karena itu, segala aktivitas perusahaan harus memuaskan para pelanggan.

2. Respek Terhadap Setiap Orang

Di dalam perusahaan yang sedang menerapkan TQM, setiap karyawan dilihat aktifitasnya dan dilihat seberapa jauh mereka memiliki talenta dan kreativ yang khas. Untuk itu, karyawan merupakan sumber daya organisasi yang paling bernilai. Oleh karena itu, setiap orang dalam sebuah organisasi diperlakukan dengan baik dan diberi kesempatan untuk terlibat dan berpartisipasi dalam tim pengambil keputusan.

3. Manajemen Berdasarkan Fakta

Prinsip ini ditekankan laporan harus didasarkan dengan data,tidak hanya sekedar pada perasaan (feeling). Ada dua konsep pokok yang berkaitan dengan hal ini. Pertama prioritas (prioritization), yakni suatu konsep bahwa perbaikan tidak dapat dilakukan di semua aspek pada saat yang bersamaan, mengingat 
keterbatasan sumber daya yang ada. Oleh karena itu, dengan menggunakan data, maka manajemen dan tim dalam organisasi dapat memfokuskan usahanya pada situasi tertentu yang vital. Konsep kedua, variasi atau nilai kinerja manusia. Data statistic dapat memberikan gambaran mengenai variabilitas yang merupakan bagian yang wajar dari setiap sistem organisasi. Dengan demikian, manajemen dapat memprediksi hasil dari setiap keputusan dan tindakan yang dilakukan.

4. Perbaikan Berkesinambungan

Agar dapat sukses bersama, disetiap perusahaan harus melakukan segala usaha untuk menguraikan dan merumuskan sesuatu dalam hubungan yang teratur dan logis sehingga membentuk suatu sistem yang utuh. Konsep ini terdiri dari langkah-langkah perencanaan, dan melakukan tindakan korektif terhadap hasil yang diperoleh.

\section{Total Quality Management (Manajemen Mutu Terpadu)}

Belakangan ini, konsep Manajemen Mutu sangat pesat dan dan ditekankan untuk diterapkan, khususnya dalam dunia pendidikan. Mutu pendidikan (lulusan) tidak hanya ditentuka oleh satu guru akan tetapi ditentukan oleh semua guru sekolah, yaitu pengelola dan staf administrasi.

Dan dibawah ini ada beberapa alasan mengapa TQM harus di terapkan di lembaga pendidikan:

1. Semua pendidik mempunyai tanggung jawab yang sangat besar terhadap bisnis tersebut karena pendidik adalah pendorong utama untuk meningkatkan sekolah/lembaga tersebut.

2. Pendidikan sangat membutuhkan proses yang bisa menyelesaikan masalah-masalah yang peka dan yang berkaitan dengan aktifitas 
dan penyelesaian penyebab utama yang dapat menimbulkan masalah tersebut.

3. Organisasi sekolah harus menjadi rencana organisasi belajar semua organisasi.

4. Dengan semua penerapan TQM tersebut mungkin bisa memberikan sistem yang lebih baik kedepannya, karna menerapakan TQM di sekolah kita dapat menemukan sistem mna saja yang tidak berjalan dengan baik di saat ini.$^{15}$

TQM (Manajemen Mutu Terpadu) merangkumkan semua konsep tentang kualitas; karenanya semua itu disebut sebagai pengelolaan kualitas secara menyeluruh. TQM itu menekankan pada personal, etika, budaya, dan juga memberikan sistem kualitas yang terarah dari setiap anggota organisasi dalam usaha perbaikan yang terus menerus. ${ }^{16}$

Dari semu ahli manajemen mengungkapkan bahwa pengertian Total Quality Managementt (Manajemen Mutu Terpadu) diantaranya adalah : Menurut Edward Sallis (1993: 13) bahwa : "Total Quality Manajemen is a philosophy and a methodologhy wich assist institutions to manage change and set their own agendas for dealing with the plethora of new external pressures."17

\footnotetext{
${ }^{15}$ Veithzal Rivai dan sylviana Murni, Education Management, Jakarta Rajawali Pres 2010, h. $483-484$

${ }^{16}$ Agus Fahmi, Manshur Ghani Sanusi, Konsep Pendidikan Modern (Surabaya : SMA Khadijah, 2006), h.67

${ }^{17}$ Ibid, hal 68
} 


\section{PENUTUP}

Quality (Mutu) dalam kondisi tersebut ialah hasil pendidikan megarah kepada keberhasilan yang telah dicapai oleh sekolah pada setiap kurun waktu tertentu baik dalam bidang akademik atau dalam bidang non akademik.

Total Quality Management (Manajemen Mutu Terpadu) ialah suatu pendekatan yang keberadaannya dapat peningkatan mutu produk yang dihasilkan oleh sebuah lembaga, dan juga organisasi yang harus ditingkatkan untuk kepuasan pelanggan dan untuk mencegah dari lingkungan yang terus berubah. Dan jugas harus ada perbaikan dari lembaga yang terus menerus.

Dan juga ada prinsip-prinsip Total Quality Manajemen yaitu,kepuasan pelanggan di mana suatu lembaga harus berusaha memberikan produk yang berkualitas agar tidak ada ketidak puasan dari pelanggan,yang kedua respek terhadap setiap orang, dan karyawan harus mmberikan rasa hormat kepada pelanggan agar ada rasa kekaguman dan bisa dibilang bisa saling menghormati terhadap orang lain,yang ketiga ialah manajemen berdasarkan fakta apa yang telah di keluarkan oleh lembaga itu harus nyata tidak ada kebohongan sama sekali dan pelanggan bisa mempercai lembaga tersebut,dan yang terakhir perbaikan kesinambungan disetiap perusahaan harus melakukan segala usaha untuk menguraikan dan merumuskan sesuatu dalam kebersamaan dalam organisasi tersebut dan menjalin hungan yang baik agar di dalam organisasi tersebut bisa menjadi organisasi yang baik dan utuh. 


\section{DAFTAR PUSTAKA}

Gaspersz, Vincent. 2001. Total Quality Manajemen. PT Gramedia Pustaka Utama, Jakarta.

Purnama, Nursya'bani. 2006. Manajemen Kualitas Perspektif Global. Ekonisia, Yogyakarta.

Hitt,Michael A, R.Duane Ireland dan Robert E. Hoskisson. 2001. Manajemen Strategis : Daya Saing dan Globalisasi. Salemba Empat, Jakarta.

Nasution, M.N.2004. Manajemen Mutu Terpadu ( Total Quality Management). Ghalia Indonesia, Jakarta.

Ibrahim, Buddy. 2000. TQM (Total Quality Management) : Panduan Menghadapi Persaingan Global. Djambatan, Jakarta.

Partanto, Pius A. 1994. Kamus Ilmiah Populer. Arkola, Surabaya.

Riyadi, Ali, Ahmad. 2007. Manajemen Mutu Pendidikn. Ircisod, Yogyakarta.

Rosyada, Dede. 2004. Paradigma Pendidikan Demokratis; Sebuah Model Perlibatan Masyaraka dalam Penyelenggaraan pendidikan. Kencana, Jakarta. 
Mulyadi. 1998. Total Quality Manajemen.UGM, Yogyakarta.

Hasibuan, S.P, Malayu. 2000. Manajemen Sumber Daya Manusia. Bumi Aksara, Jakarta. 